\title{
Quantitative Analysis of Medicinal plants used by the Traditional healers of Karanja block of Wardha district for treating Musculoskeletal disorders
}

\author{
Research Article
}

\section{Bharat Rathi ${ }^{*}$, Renu Rathi²}

\author{
1. Professor, Department of Rasashastra, 2. Professor, Department of Kaumarabhritya, \\ Mahatma Gandhi Ayurveda College Hospital \& Research Centre, Salod (H) Wardha, (MS), India \\ Datta Meghe Institute of Medical Sciences (Deemed to be University) Sawangi (Meghe) Wardha, India
}

\begin{abstract}
Background: $20 \%$ to30 \% elderly population suffers with Musculoskeletal disorders such as Multiple joint pains, Low back pain, Rheumatoid arthritis, Osteoarthritis. Multiple treatment modalities are in vogue to treat MSDs all over the world but neither provides adequate pain relief nor modifies the disease process. Hence majority of the tribal population prefer traditional healers for treating MSDs as they are safe, effective, inexpensive and easily available. Aim \& Objectives: Quantitative analysis of Medicinal plants used by the traditional healers of Karanja block of Wardha district for treating musculoskeletal disorders. Material \& Methods: The survey study was carried out through field visits. Questionnaire, personal interviews and discussions with the traditional healers were used for data collection. Specific pharmacological properties of herbal drugs used by the traditional healers to treat MSDs were authenticated by taxonomist and forest range officer and verified through Nighantus and Samhitas. Observations \& results: Total 17 traditional healers were interviewed for data collection. Total 23 plant species belonging to 20 families were identified and documented for the treatment of MSDs. Tribal utilized 9 varieties of plant parts from 4 types of habitat and treat the patients of MSDs with 5 types of medicinal preparations through external and internal applications.
\end{abstract}

Key Words: Survey, Musculo-skeletal diseases, Traditional healers, Plant species.

\section{Introduction}

Musculoskeletal disorder (MSD) is the term, used to expound the range of states that involve joints, muscles, tendons, ligaments and connective tissues, which are normally progressive and associated with pain(1). The most common musculoskeletal conditions are osteoarthritis, back and neck pain, fractures associated with bone fragility, injury and systemic inflammatory conditions such as rheumatoid arthritis(2). The most common feature of musculoskeletal disease is pain and restricted mobility which weakened people's capability to work. In Ayurveda MSDs are described under the heading of Vatavyadhi which involves all types of musculoskeletal disorders and caused by viatiated vata. Ayurved intensely describes various varieties of osteoarthritis as Sandhivata and rheumatoid arthritis as Amavata. The management of Vatavyadhis mainly aims at alleviating Vata by inducing drugs with opposite qualities.

Osteoarthritis primarily affects the elderly population. According to the data by WHO, between $20-30 \%$ of people across the globe live with a painful

\section{* Corresponding Author:}

\section{Bharat Rathi}

Professor, Department of Rasashastra \& Bhaishajya Kalpana, Mahatma Gandhi Ayurveda College Hospital \& Research Centre, Salod (H) Wardha, (MS), India Email Id: bharatrathi174@gmail.com musculoskeletal conditions of which $9.6 \%$ of men and $18.0 \%$ of women aged over 60 years have symptomatic osteoarthritis. $80 \%$ of those with osteoarthritis have limitations in movement and $25 \%$ cannot perform their major daily activities of life. Thus it is a major cause of disability in older adults worldwide (3). In India, it is prevalent with $22 \%$ to $39 \%$, where nearly $45 \%$ of women over the age of 65 years suffered with OA (4).

Different treatment modalities are used to treat MSDs all over the world which includes ultrasound treatment, administration of analgesics and Non Steroidal Anti-inflammatory Drugs (NSAIDs), disease modifying anti-rheumatic drugs (DMARDs) but their use neither provides adequate pain relief nor modifies the disease process. In addition, these managements are costlier for the general public and associated with side effects $(5,6)$. Due to this reason, tribal communities prefer alternate herbal therapies to treat MSD disorders (7). Herbal medicines used by traditional healers play an important role to combat Musculoskeletal disorders as they are safe, effective, inexpensive and easily available (8). A study conducted by D. Gupta et al emphasized that nearly $70 \%$ of patients suffering with MSDs prefer these alternate herbal therapies (9).Number of tribal communities reside in the villages of Karanja Ghadge block of Wardha district, Maharashtra, India. Most of the tribes have a deep knowledge of medicinal plants and use plants from adjoining forests to treat diseases of local population. Systematic ethno medicinal study of medicinal plants 
used in this region for treating MSDs has not yet been carried out. In this survey study, hence an attempt is made to document the herbal medicinal plants used by the tribal healers to treat the musculoskeletal disorders of Karanja Ghadge block of Wardha district.

\section{Material \& Methods}

The survey study was carried out in the Karanja block of Wardha district through field visits during October 2018 to March 2019 in different remote villages where the tribal communities live. Traditional healers were indentified with the help of local people and forest department personnel familiar with them. Interviews were arranged with the tribal healers and data regarding treatment of various musculoskeletal disorders was collected using questionnaire and direct discussions with the tribal healers. The questionnaire included the information such as common name, habit, plant parts used, method of preparation and mode of application. The medicinal plant species used by the traditional healers to treat various musculoskeletal disorders of the study area were authenticated by taxonomist and forest range officer. Their specific pharmacological properties were verified through Nighantus and Samhitas. Their anti inflammatory, analgesic or anti arthritic activity were also searched through various preclinical and clinical studies. Descriptive statistic was used to analyze the data.

\section{Observation and Results}

Karanja is a tahsil block located $59 \mathrm{Km}$ towards North from District headquarter Wardha. It is a tribal prone block where tribal communities dwell in small groups in different villages and mostly receive herbal medication from traditional healers for their ailments. Total 17 tribal traditional healers commonly known as Vaidu were indentified and interviewed. All were treating with herbs available around them and practicing since 5 years to 15 years. All the healers were in the range of 48 to 82 years and most them carrying the family tradition of herbal treatment. All these tribes speak Marathi language for communication, belonged to farming, cattle grazer, shepherds and farm worker category.

\section{Fig 1: Map showing Fig 2: Map showing the dis t rict of the location of Study Vidarbha Region area of Wardha Maharashtra.}

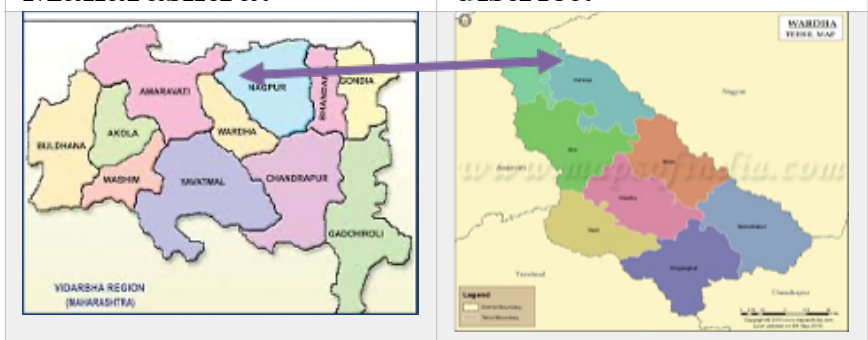

Table 1: List of plant species used by the traditional healers to treat musculoskeletal disorders

\begin{tabular}{|c|c|c|c|c|c|c|c|}
\hline S.N. & $\begin{array}{l}\text { Botanical } \\
\text { name }\end{array}$ & Family & $\begin{array}{l}\text { Local } \\
\text { Name }\end{array}$ & Sanskrit name & Habitat & $\begin{array}{l}\text { Part } \\
\text { Used }\end{array}$ & $\begin{array}{l}\text { Method of Preparation } \\
\text { and Mode of application }\end{array}$ \\
\hline 1 & $\begin{array}{l}\text { Acacia arabica } \\
\text { (Lam) Willd }\end{array}$ & Leguminoceae & Babhul & Babbul & Tree & Fruit & $\begin{array}{l}\text { Seeds are removed and fruit } \\
\text { pulp is made in to fine } \\
\text { Powder and given orally } \\
\text { twice a day in Knee pain. }\end{array}$ \\
\hline 2 & $\begin{array}{l}\text { Allium satium } \\
\text { ( L.) }\end{array}$ & Liliaceae & Lasan & Rason & shrub & tuber & $\begin{array}{l}\text { Tubers are peeled off and } \\
\text { crushed into Paste and } \\
\text { applied on swollen joints } \\
\text { (Aamavata) }\end{array}$ \\
\hline 3 & $\begin{array}{l}\text { Argyreia } \\
\text { speciosa } \\
\text { Sweet. }\end{array}$ & Convolvulaceae & Vidhara & Samudr shosha & Climber & $\begin{array}{l}\text { Seeds, } \\
\text { leaves }\end{array}$ & $\begin{array}{l}\text { The seeds are dried and } \\
\text { powdered. } 2-3 \text { gm with milk } \\
\text { in arthritis } \\
\text { Paste of leaves applied on } \\
\text { swollen joints. }\end{array}$ \\
\hline 4 & $\begin{array}{l}\text { Astercantha } \\
\text { longifolia (L.) } \\
\text { Ness }\end{array}$ & Acanthaceae & Kolistha & $\begin{array}{l}\text { Talimkhana } \\
\text { Kokilaksha }\end{array}$ & Herb & Seeds & $\begin{array}{l}\text { The seeds are dried and } \\
\text { powdered. } 2-3 \text { gm with } \\
\text { water in arthralgia }\end{array}$ \\
\hline 5 & $\begin{array}{l}\text { Calotropis } \\
\text { gigantea }(\mathrm{L} .)\end{array}$ & Asclepideaceae & Rui & Arka & Shrub & $\begin{array}{l}\text { Flower } \\
\mathrm{s}\end{array}$ & $\begin{array}{l}\text { Flowers are dried and finely } \\
\text { powdered. } 1 \text { gm powder } \\
\text { with warm water in swollen } \\
\text { and painful joints. }\end{array}$ \\
\hline 6 & $\begin{array}{l}\text { Celestrus } \\
\text { paniculata } \\
\text { Willd. }\end{array}$ & Celastraceae & Malkangini & Jyotishmati & Climber & Seeds & $\begin{array}{l}\text { Seeds are crushed and } \\
\text { boiled in sesame oil till it } \\
\text { turns red and filtered. } \\
\text { Applied externally on } \\
\text { painful joints and stiffness }\end{array}$ \\
\hline 7 & $\begin{array}{l}\text { Cocculus } \\
\text { hirsutus L. }\end{array}$ & Menispermaceae & Vasanvel & Patalgarudi & Climber & Leaves & $\begin{array}{l}\text { Fine paste of leaves is } \\
\text { prepared and applied warm } \\
\text { on swollen joints once in a } \\
\text { day. }\end{array}$ \\
\hline
\end{tabular}




\begin{tabular}{|c|c|c|c|c|c|c|c|}
\hline 8 & $\begin{array}{l}\text { Curcuma } \\
\text { amada } \\
\text { Roxb }\end{array}$ & Zingiberaceae & Ambehalad & Amraharidra & Herb & Tuber & $\begin{array}{l}\text { Fine paste is prepared and } \\
\text { applied on sprain and } \\
\text { abrasions }\end{array}$ \\
\hline 9 & $\begin{array}{l}\text { Abutilon } \\
\text { indicum Linn }\end{array}$ & Malvaceae & Petari & Atibala & Shrub & $\begin{array}{l}\text { Whole } \\
\text { plant }\end{array}$ & $\begin{array}{l}\text { Whole pant is dried and } \\
\text { pound to make fine Powder. } \\
1-2 \text { gm with milk in arthritis } \\
\text { in elderly person }\end{array}$ \\
\hline 10 & $\begin{array}{l}\text { Pluchea } \\
\text { lanceolata } \\
\text { (DC.) Olive. \& } \\
\text { Hiern }\end{array}$ & Asteraceae & Rasan & Rasana & Shrub & $\begin{array}{l}\text { Whole } \\
\text { plant }\end{array}$ & $\begin{array}{l}\text { Dried drug is pounded and } \\
\text { finely powdered. } 1-2 \mathrm{gm} \\
\text { with warm water Amavata } \\
\text { and Sandhivata }\end{array}$ \\
\hline 11 & $\begin{array}{l}\text { Lepidium } \\
\text { satium (Fam.) }\end{array}$ & Cruciferae & Aahaliv & Chandrashur & Shrub & Seeds & $\begin{array}{l}\text { Seeds are made into fine } \\
\text { Paste and applied warm on } \\
\text { swollen joints (Amavata) }\end{array}$ \\
\hline 12 & $\begin{array}{l}\text { Litsea } \\
\text { glutinosa } \\
\text { (Lour.) C.B. }\end{array}$ & Lauraceae & $\begin{array}{l}\text { Maidalakdi } \\
\text { Lenja }\end{array}$ & Medasak & Tree & Bark & $\begin{array}{l}\text { Fine paste of bark is } \\
\text { prepared and applied warm } \\
\text { on sprain, abrasions for } \\
\text { relieving pain. }\end{array}$ \\
\hline 13 & $\begin{array}{l}\text { Moringa } \\
\text { pterygosperma } \\
\text { Gaertn }\end{array}$ & Moringaceae & Shevga & Shigru & Tree & $\begin{array}{l}\text { Bark, } \\
\text { Gum }\end{array}$ & $\begin{array}{l}\text { Fine paste of bark is } \\
\text { prepared and applied warm } \\
\text { on painful joints. } \\
\text { Powder of gum resin is } \\
\text { given } 1 \text { gm / day to elderly } \\
\text { arthritis and low backache }\end{array}$ \\
\hline 14 & $\begin{array}{l}\text { Oroxylum } \\
\text { indicum vent. }\end{array}$ & Bignoniaceae & Tentu & Shyonak & Tree & Bark & $\begin{array}{l}\text { The bark is coarsely } \\
\text { powdered \& boiled with } 4 \\
\text { times water on low flame } \\
\text { and filtered the decoction. } \\
\text { Dose- } 40 \mathrm{ml} \text { twice a day }\end{array}$ \\
\hline 15 & $\begin{array}{l}\text { Phyllanthus } \\
\text { urinaria (L.) }\end{array}$ & Euphorbiaceae & Bhuiaavli & Bhumyamalki & Herb & $\begin{array}{l}\text { Whole } \\
\text { plant }\end{array}$ & $\begin{array}{l}\text { Paste of whole plant is } \\
\text { prepared and applied as a } \\
\text { poultice on knee joint } \\
\text { swelling. }\end{array}$ \\
\hline 16 & $\begin{array}{l}\text { Pongamia } \\
\text { glabra (L.) }\end{array}$ & Leguminoceae & Karanji & Karanj & Tree & Leaves & $\begin{array}{l}\text { Fresh matured leaves are } \\
\text { crushed \& boiled with } 4 \\
\text { times water on low flame } \\
\text { and filtered the decoction. } \\
20 \mathrm{ml} \text { twice. }\end{array}$ \\
\hline 17 & $\begin{array}{l}\text { Premna } \\
\text { imtegrefolia } \\
\text { (L.) }\end{array}$ & Verbenaceae & Takli & Agnimanth & Tree & Leaves & $\begin{array}{l}\text { Leaves are made warm and } \\
\text { applied on painful joints. } \\
\text { Tender leaves paste is } \\
\text { prepared and applied warm } \\
\text { on sprain. }\end{array}$ \\
\hline 18 & $\begin{array}{l}\text { Ricinus } \\
\text { communis (L.) }\end{array}$ & Euphrobiaceae & Erandi & Erand & Shrub & Leaves & $\begin{array}{l}\text { The leaves are cut into small } \\
\text { pieces, slightly fried in the } \\
\text { oil and made into poultice } \\
\text { and used hot fomentation } \\
\text { on joint stiffness }\end{array}$ \\
\hline 19 & $\begin{array}{l}\text { Terminalia } \\
\text { arjuna Wight } \\
\text { \& Arn }\end{array}$ & Combretaceae & Aajan saal & Arjun & Tree & Bark & $\begin{array}{l}\text { Bark decoction is given } \\
\text { orally and fine paste of bark } \\
\text { is applied externally on ribs } \\
\text { fracture. }\end{array}$ \\
\hline 20 & $\begin{array}{l}\text { Tinospora } \\
\text { cordifolia } \\
\text { (Thunb) }\end{array}$ & Menispermaceae & Gulvel & Guduchi & Climber & Stem & $\begin{array}{l}\text { Fresh stem are cut into } \\
\text { small pieces, boiled with } \\
\text { water \&decoction is } \\
\text { filtered . } 40 \mathrm{ml} \text { BD in gouty } \\
\text { arthritis( Vatarakta) }\end{array}$ \\
\hline 21 & $\begin{array}{l}\text { Trigonella } \\
\text { foenum } \\
\text { graecum } \\
\text { (Linn.) }\end{array}$ & Fabaceae & Methya & Methika & Herb & Seeds & $\begin{array}{l}\text { Seeds are pounded and } \\
\text { made into fine Powder. 1-2 } \\
\text { gm with warm water in } \\
\text { elderly joint pain and back } \\
\text { pain }\end{array}$ \\
\hline
\end{tabular}




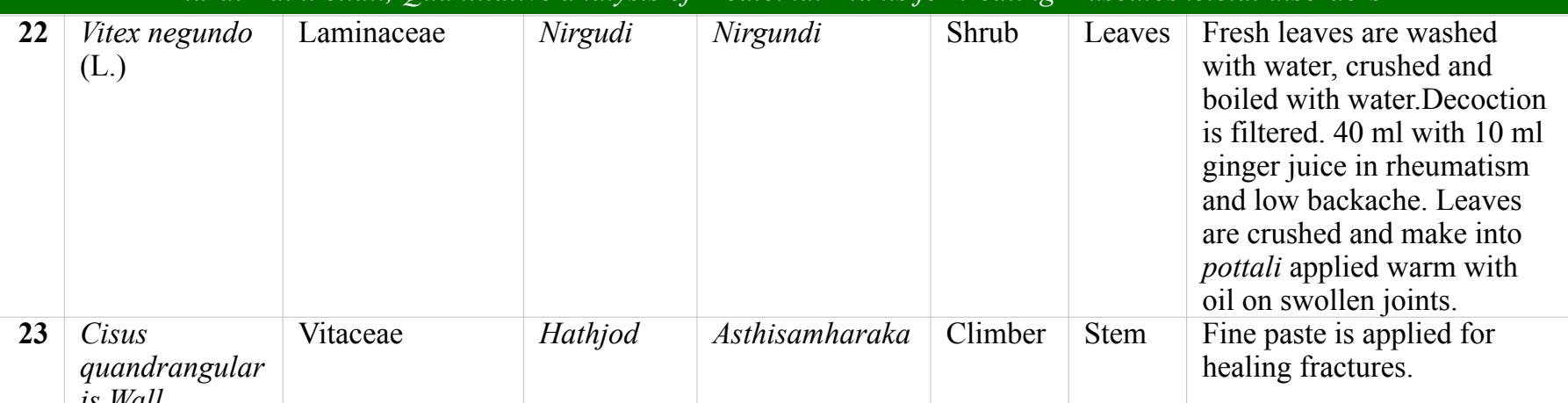

Table 2: Pharmacological properties of the plant species used by the tribes to treat MSDs

\begin{tabular}{|c|c|c|c|c|c|c|c|}
\hline S.N. & Drug name & $\begin{array}{l}\text { Pharmacological } \\
\text { properties } \\
\text { Rasa }\end{array}$ & Guna & Virya & Vipak & Effect on Dosha & References \\
\hline 1 & $\begin{array}{l}\text { Acasia arebica } \\
\text { (Lam) Willd }\end{array}$ & Madhur, Kashaya & $\begin{array}{l}\text { Guru, } \\
\text { Rukhsa }\end{array}$ & Shita & Madhur & $\begin{array}{l}\text { Pitta vata } \\
\text { shamak }\end{array}$ & $\begin{array}{l}\text { B.P. } \\
6 / 36-37\end{array}$ \\
\hline 2 & $\begin{array}{l}\text { Abutilon } \\
\text { indicum Linn. }\end{array}$ & Madhura & $\begin{array}{l}\text { Guru, } \\
\text { Snigdha, } \\
\text { Pichhil }\end{array}$ & Shita & Madhur & Vatahara & $\begin{array}{l}\text { C. S. } \\
\text { Su. } 25 / 40\end{array}$ \\
\hline 3 & $\begin{array}{l}\text { Allium satium } \\
\text { ( L.) }\end{array}$ & $\begin{array}{l}\text { All five rasas except } \\
\text { Lavan }\end{array}$ & $\begin{array}{l}\text { Snigdh, } \\
\text { Tikshna, } \\
\text { sara }\end{array}$ & Ushna & Katu & $\begin{array}{l}\text { Shothahar, } \\
\text { Vathara }\end{array}$ & $\begin{array}{l}\text { C.S.Su } \\
27 / 176\end{array}$ \\
\hline 4 & $\begin{array}{l}\text { Argyreia } \\
\text { speciosa } \text { Sweet. }\end{array}$ & Katu, Tikta Kashaya & $\begin{array}{l}\text { Laghu, } \\
\text { Snigdh }\end{array}$ & Ushna & Madhur & Kaphavatahar & $\begin{array}{l}\text { B.P.3/211-2 } \\
12\end{array}$ \\
\hline 5 & $\begin{array}{l}\text { Astercantha } \\
\text { longifolia (L.) }\end{array}$ & Madhur, Amla, Tikta & $\begin{array}{l}\text { Pichhil, } \\
\text { Snigdha }\end{array}$ & Shita & Madhur & Vatahara & $\begin{array}{l}\text { B.P.3/224- } \\
225\end{array}$ \\
\hline 6 & $\begin{array}{l}\text { Calotropis } \\
\text { gigantea }(\mathrm{L} .)\end{array}$ & Katu. Tikta & $\begin{array}{l}\text { Laghu, } \\
\text { Ruksha, } \\
\text { Tikshna }\end{array}$ & Ushna & Katu & $\begin{array}{l}\text { Shothar, } \\
\text { Kaphavatahar }\end{array}$ & $\begin{array}{l}\text { B.P.3/67-6 } \\
9\end{array}$ \\
\hline 7 & $\begin{array}{l}\text { Celestrus } \\
\text { paniculata } \\
\text { Willd. }\end{array}$ & Katu. Tikta & $\begin{array}{l}\text { Tikshna, } \\
\text { Sara }\end{array}$ & Ushna & Katu & Vatakaphahar & $\begin{array}{l}\text { B.P.1/171- } \\
172\end{array}$ \\
\hline 8 & $\begin{array}{l}\text { Cocculus } \\
\text { hirsutus (L.) }\end{array}$ & Katu & $\begin{array}{l}\text { Laghu, } \\
\text { Snigdha, } \\
\text { Pichhila }\end{array}$ & Ushna & Katu & Vatashamak & B.P.3/260 \\
\hline 9 & $\begin{array}{l}\text { Curcuma amada } \\
\text { Roxb }\end{array}$ & Tikta, Katu & $\begin{array}{l}\text { Ruksha, } \\
\text { Laghu }\end{array}$ & Shita & Katu & Vatakar & $\begin{array}{l}\text { B.P.1/198- } \\
199\end{array}$ \\
\hline 10 & $\begin{array}{l}\text { Inula recemosa } \\
\text { (Hook,f.) }\end{array}$ & Tikta, Katu & $\begin{array}{l}\text { Laghu, } \\
\text { Tikshna }\end{array}$ & Ushna & Katu & Vatakaphahar & B.P.1/165 \\
\hline 11 & $\begin{array}{l}\text { Lepidium satium } \\
\text { (Fam.) }\end{array}$ & Katu, Tikta & $\begin{array}{l}\text { Laghu, } \\
\text { Snigdha, } \\
\text { Pichhila }\end{array}$ & Ushna & Katu & Vatakaphahar & $\begin{array}{l}\text { B.P.1/96-9 } \\
7\end{array}$ \\
\hline 12 & $\begin{array}{l}\text { Litsea glutinosa } \\
\text { (Lour.)C.B. }\end{array}$ & $\begin{array}{l}\text { Katu, Tikta, } \\
\text { Kashaya }\end{array}$ & $\begin{array}{l}\text { Laghu, } \\
\text { Snigdha }\end{array}$ & Ushna & Katu & Kaphavatshamak & $\begin{array}{l}\text { B.P.app } \\
1 / 92\end{array}$ \\
\hline 13 & $\begin{array}{l}\text { Moringa } \\
\text { pterygosperma } \\
\text { Gaertn }\end{array}$ & Katu, Madhur & $\begin{array}{l}\text { Laghu, } \\
\text { Tikshna }\end{array}$ & Ushna & Katu & Kaphavatshamak & B..P 3/105 \\
\hline 14 & $\begin{array}{l}\text { Oroxylum } \\
\text { indicum vent. }\end{array}$ & Tikta, Kashaya & $\begin{array}{l}\text { Laghu, } \\
\text { Ruksha }\end{array}$ & Shita & Katu & Tridoshahara & B.P.3/25 \\
\hline 15 & $\begin{array}{l}\text { Phyllanthus } \\
\text { urinaria }(\mathrm{L}) .\end{array}$ & $\begin{array}{l}\text { Tikta, Kashaya, } \\
\text { Madhur }\end{array}$ & $\begin{array}{l}\text { Laghu, } \\
\text { Ruksha }\end{array}$ & Shita & Madhur & $\begin{array}{l}\text { Kaphapitta } \\
\text { shamak }\end{array}$ & $\begin{array}{l}\text { K.N.Ausha } \\
\text { dhi varga / } \\
247\end{array}$ \\
\hline 16 & $\begin{array}{l}\text { Pongamia } \\
\text { glabra (L.) }\end{array}$ & Tikta, Katu, Kashaya & $\begin{array}{l}\text { Laghu. } \\
\text { Tikshna }\end{array}$ & Ushna & Katu & $\begin{array}{l}\text { Kaphavat } \\
\text { shamak }\end{array}$ & $\begin{array}{l}\text { K.N.Ausha } \\
\text { dhi vargal } \\
664\end{array}$ \\
\hline 17 & $\begin{array}{l}\text { Premna } \\
\text { imtegrefolia (L.) }\end{array}$ & Tikta, Katu, Madhur & $\begin{array}{l}\text { Laghu, } \\
\text { Ruksha }\end{array}$ & Ushna & Katu & Kaphavathar & $\begin{array}{l}\text { B.P.3/23-2 } \\
4\end{array}$ \\
\hline 18 & $\begin{array}{l}\text { Ricinus } \\
\text { communis (L.) }\end{array}$ & $\begin{array}{l}\text { Madhur, Katu, } \\
\text { Kashaya }\end{array}$ & $\begin{array}{l}\text { Laghu, } \\
\text { Ruksha }\end{array}$ & Ushna & Madhur & Vatahara & $\begin{array}{l}\text { B.P. } \\
\text { 3/64-66 }\end{array}$ \\
\hline
\end{tabular}


International Journal of Ayurvedic Medicine, Vol 11 (2), 175-183

\begin{tabular}{|l|l|l|l|l|l|l|l|}
\hline $\mathbf{1 9}$ & $\begin{array}{l}\text { Terminalia } \\
\text { arjuna Wight \& } \\
\text { Arn }\end{array}$ & Kashaya & $\begin{array}{l}\text { Laghu, } \\
\text { Ruksha }\end{array}$ & Sheet & Katu & $\begin{array}{l}\text { Kaphapitta } \\
\text { shamak }\end{array}$ & $\begin{array}{l}\text { B.P.5/26-2 } \\
7\end{array}$ \\
\hline $\mathbf{2 0}$ & $\begin{array}{l}\text { Tinospora } \\
\text { cordifolia } \\
\text { (Thunb) }\end{array}$ & Katu, Tikta & $\begin{array}{l}\text { Laghu, } \\
\text { Snigdha }\end{array}$ & Ushna & Madhur & Vatahara & B.P. 3/1-10 \\
\hline $\mathbf{2 1}$ & $\begin{array}{l}\text { Trigonella } \\
\text { foenum graecum } \\
\text { Linn.) }\end{array}$ & Katu & $\begin{array}{l}\text { Laghu, } \\
\text { Ruksha } \\
\text { (L.) }\end{array}$ & Ushna & Katu & Vatashaman & B.P.1/93/95 \\
\hline $\mathbf{2 2}$ & $\begin{array}{l}\text { Katu,Tikta, } \\
\text { Kashaya }\end{array}$ & $\begin{array}{l}\text { Laghu, } \\
\text { Ruksha }\end{array}$ & Ushna & Katu & Kaphavathara & $\begin{array}{l}\text { R.N.Shatav } \\
\text { hadi } \\
\text { varga /152 }\end{array}$ \\
\hline $\begin{array}{l}\text { Vitis } \\
\text { quandrangularis } \\
\text { Wall. }\end{array}$ & Madhur & Laghu & Ushna & Katu & Vatakaphahar & $\begin{array}{l}\text { B.P.3/226- } \\
227\end{array}$ \\
\hline
\end{tabular}

BP- Bhavprakash, C.S.- Charaka Samhita, Su.-Sutrasthana, K.N.- Keydev Nighantu, R.N.- Raj Nighantu

Graph 1: Habitat wise analysis of documented Ethno-medicinal plants (\%)

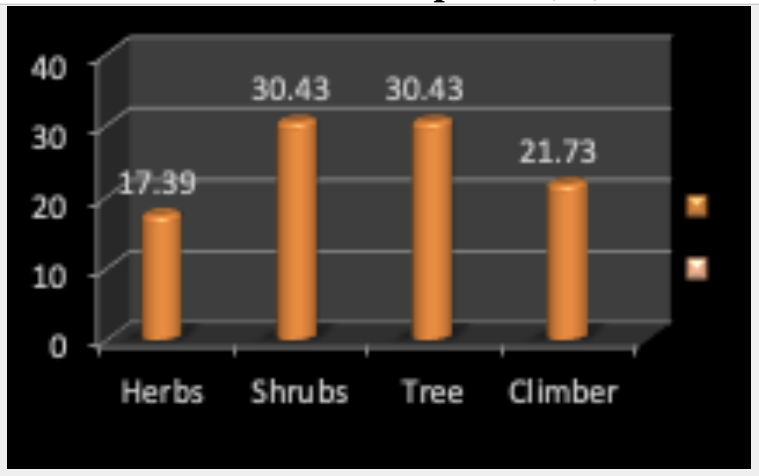

Graph 3: Percentage of herbal preparations in the treatment $(\%)$

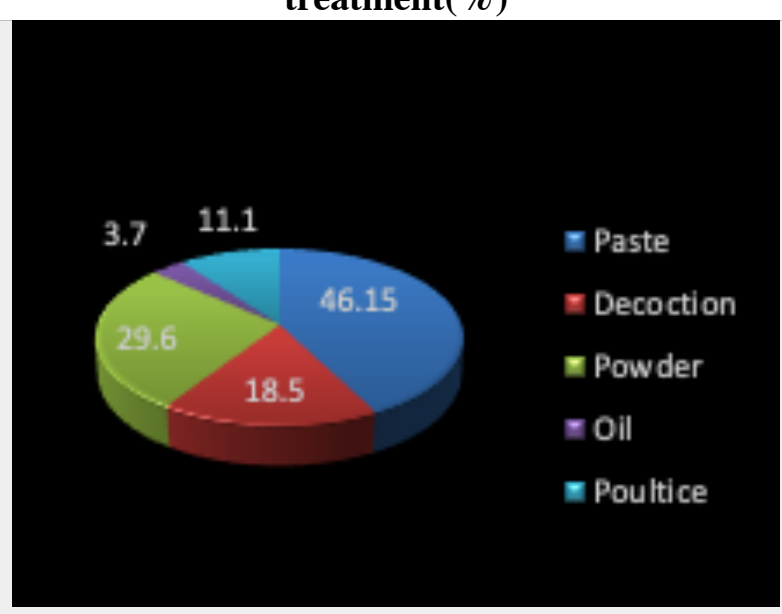

\section{Discussion}

In the present study total 23 plant species belonging to 20 families were identified and documented for the treatment of musculoskeletal disorders as depicted in Table no 1. Total 4 types of habitat were recognized out of the 23 medicinal plant species identified. They were herbs (4 species), Shrubs and trees ( 7 species each) climbers (5 species) as depicted in Graph 1. This classification revealed that shrubs and trees $(30.43 \%)$ were the most commonly used plant habitat by the traditional healers for treating the musculoskeletal disorders in the study area. This
Graph 2: Percentage of Plants parts used for the preparation of medicine $(\%)$

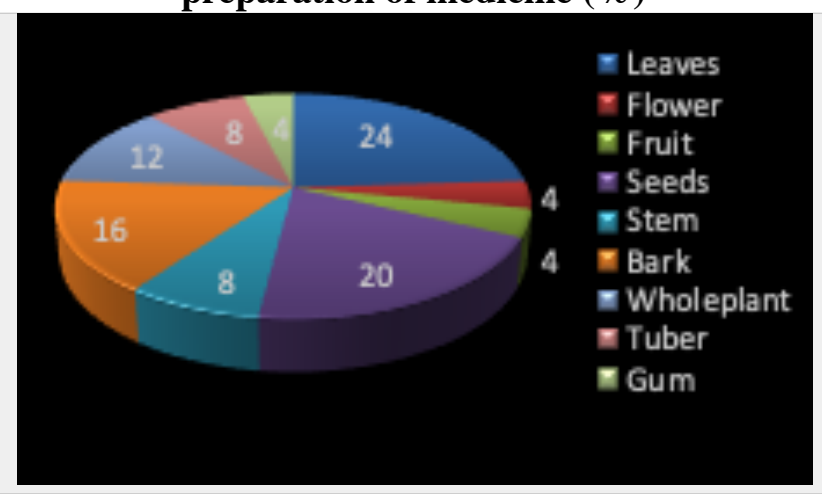

Graph 4: Root of administration of prepared medicine in the study area $(\%)$

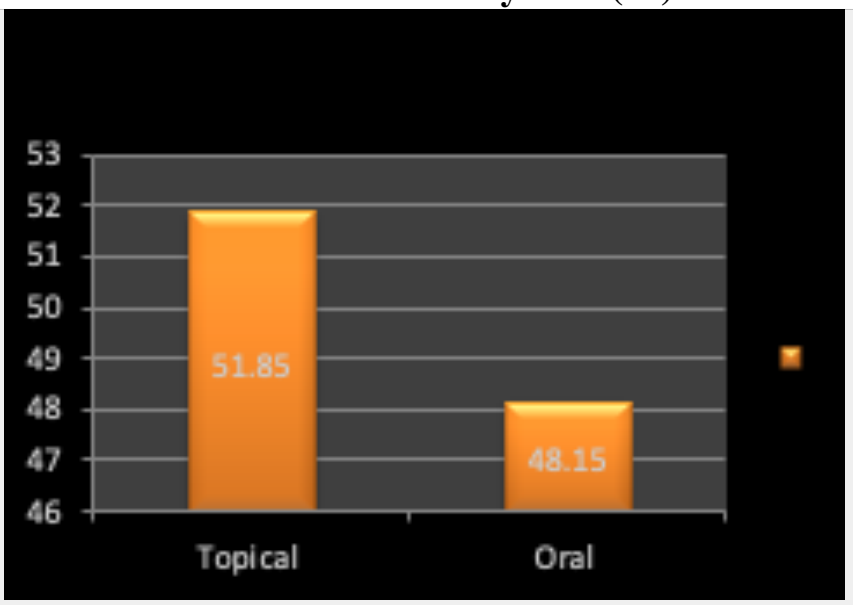

could be due to availability of shrubs and trees in large quantity throughout the year and its utility by the traditional healers in the study area. The most appearing family were Leguminoceae, Menispermaceae and Euphrobiaceae with two species each while Acanthaceae, Liliaceae, Convovulaceae, Asclepideaceae, Combretaceae, Celastraceae Fabaceae, Laminaceae, Zingiberaceae, Tiliaceae, Compositeae, Cruciferae, Lauraceae, Moringaceae, Bignoniaceae, Verbenaceae, Vitaceae were with one species each.

Although all the plant parts are utilized for medicinal purpose, conversely it is observed in the 
present study that leaves of the plant species were the most frequently utilized plant part with

$24 \%$ applications in patients followed by seeds $(20 \%)$ stem bark (16\%), whole plant (12\%), stem and tuber $(8 \%$ each) and flower, fruit and gum $(4 \%$ each) as depicted in graph 2. Khafsa Malik et al also reported that leaves were the most frequently used herbal plant part for medicinal purpose (10). Most of the musculoskeletal diseases were treated with external $(51.85 \%)$ as well as internal $(48.15 \%)$ administration of the drugs. Powder $(29.6 \%)$ and decoction $(18.5 \%)$ were the choice of preparations for internal administration where as Lepa (a method of treatment in which medicines are used topically/external application in the form of a semi-solid medicament or paste) $37 \%$, oil application $(3.7 \%)$ and Poultice $(11.1 \%)$ were used as external application on painful joints. In Ayurveda Poultice is a kind of preparation prepared by substances which are unctuous, heavy, and hot in properties, helps to pacify the vitiated vata. Generally it is used for external application (11). In Sushruta Samhita Upanaha is described as a type of sudation therapy for treating Sandhigatavata (12). According to the Benson HA, lipid medium is highly suitable for penetration of the drug molecule through stratum corneum (13). On this basis, it can be understood that the oil used in Nirgundipatra Upanaha and Erandpatra upanaha serves as a lipoidal medium for penetration of the drug molecules of Nirgundi and Erand and exerts an immediate anti-inflammatory analgesic effect (14).

In the present survey study Sandhivata (Multiple joint pain), Katishool (Low back pain),
Amavata (Rheumatoid arthritis), Sandhishotha (Swelling on joints due to vitiated vata) were reported the most common musculoskeletal conditions treated by local traditional healers and the prevalence was more in elderly patients. Atchison JW et al also reported chronic joint pain and low back pain as the frequently occurring musculoskeletal ailment (15). This survey study accounted wide use of Ricinus communis, Vitex nigundo, Cisus quandrangularis and Oroxylum indicum for treating common musculoskeletal related ailments, pain and stiffness of joints and fractures.

Most of drugs used by the traditional healers to treat musculoskeletal diseases possess Tikta Katu, Kashaya Rasa, Ushna Virya (potency), Madhura, Katu Vipaka and vatakaphahara [Table 2] In Sandhigata Vata vitiated Vata gets lodged in Sandhis (joints) hence Acharya Charaka emphasized to select those drugs having Tikta rasa to treat Vata and Asthi disorders (16). Moreover, Tikta rasa possesses Deepana (promoting digestion) Pachana (Digestive) and Rochana (Insaspissated bile) properties. Thus the general condition of the patient gets improved and reinforces the whole body as well as joints. Tikta Rasa also show Lekhana (Substances that reduce excess body tissues) property, which helps in the weight reduction of the patients and facilitate the management of Osteoarthritis. It is also showing anti inflammatory action due to its Jvarhara and Daha shamana properties and thus helps to reduce pain and swelling of the joints (17). Katu rasa and Ushna veeerya acts as a Deepan and also helps to pacify aggravated vata which is the major causative factor for MSDs (18).

Table no 4: Showing the Pharmacological actions of the drugs

\begin{tabular}{|c|c|c|c|c|}
\hline S.N. & Name of drug & $\begin{array}{l}\text { Sanskrit } \\
\text { name }\end{array}$ & Action & References \\
\hline 1 & Allium satium ( L.) & Rason & Anti-Inflammatory, Analgesic & $\begin{array}{l}\text { Jayanthi MK et al (19) } \\
\text { Suresh V et al (20) }\end{array}$ \\
\hline 2 & Argyreia speciosa Sweet. & Samudrshosha & Anti-Inflammatory, Analgesic & Bachhav RS et al (21) \\
\hline 3 & Astercantha longifolia $(\mathrm{L})$. & $\begin{array}{l}\text { Talimkhana } \\
\text { Kokilaksha }\end{array}$ & Antirheumatic & $\begin{array}{l}\text { Doss A et al (22) } \\
\text { Malrajan P et al (23) }\end{array}$ \\
\hline 4 & Calotropis gigantea (L.) & Arka & Anti-inflammatory & Das S et al (24) \\
\hline 5 & Celestrus paniculata Willd. & Jyotishmati & Anti-Inflammatory, Analgesic & $\begin{array}{l}\text { Kulkarni Y et al (25) } \\
\text { Parimala S et al (26) }\end{array}$ \\
\hline 6 & Cocculus hirsutus (L.) & Patalgarudi & Analgesic, Anti-Inflammatory & Sarvankumar G (27) \\
\hline 7 & Curcuma amada Roxb & Amraharidra & Anti inflammatory & Mujumdar AM (28) \\
\hline 8 & Abutilon indicum Linn & Atibala & $\begin{array}{l}\text { Anti-Inflammatory, Analgesic, } \\
\text { Antiarthritic }\end{array}$ & $\begin{array}{l}\text { Rajurkar et al (29) } \\
\text { Bhajipale NS et al (30) }\end{array}$ \\
\hline 9 & Pluchea lanceolata (DC.) Olive \& Heirn & Rasna & Anti-Inflammatory, Analgesic & $\begin{array}{l}\text { Pandey S et al (31) } \\
\text { Pandey PS et al (32) }\end{array}$ \\
\hline 10 & Lepidium satium (Fam.) & Chandrashur & Analgesic, Anti-Inflammatory & $\begin{array}{l}\text { Raval N et al (33) } \\
\text { Raval N et al (34) }\end{array}$ \\
\hline 11 & Litsea glutinosa (Lour.) C.B. & Medasak & $\begin{array}{l}\text { Analgesic, Antipyretic, And } \\
\text { Anti-Inflammatory }\end{array}$ & Bhowmick R etal (35) \\
\hline 12 & Moringa pterygosperma Gaertn & Shigru & $\begin{array}{l}\text { Analgesic, Antipyretic, And } \\
\text { Anti-Inflammatory }\end{array}$ & $\begin{array}{l}\text { Bhattacharya A et al } \\
\text { (36) }\end{array}$ \\
\hline 13 & Oroxylum indicum vent. & Shyonak & Anti-inflammatory & Lalrinzuali $\mathrm{K}$ et al (37) \\
\hline 14 & Phyllanthus urinaria $(\mathrm{L})$. & Bhumyamalki & Anti inflammatory & Fang SH et al (38) \\
\hline
\end{tabular}




\begin{tabular}{|c|c|c|c|c|}
\hline 15 & Pongamia glabra (L.) & Karanj & Anti-inflammatory, Analgesic & Ganesh M (39) \\
\hline 16 & Premna imtegrefolia $(\mathrm{L})$. & Agnimanth & Anti-inflammatory, Analgesic & $\begin{array}{l}\text { Gokani RH et al (40) } \\
\text { Khatun H et al (41) }\end{array}$ \\
\hline 17 & Ricinus communis (L.) & Erand & $\begin{array}{l}\text { Anti-Inflammatory, Analgesic } \\
\text { Antiarthritic }\end{array}$ & $\begin{array}{l}\text { Ilavarasan R et al (42) } \\
\text { Sapan BJ et al (43) }\end{array}$ \\
\hline 18 & Terminalia arjuna Wight \& Arn & Arjun & Analgesic & Gupta A (44) \\
\hline 19 & Tinospora cordifolia (Thunb) & Guduchi & Anti-Inflammatory, Antipyretic & $\begin{array}{l}\text { Sumanlata et al (45) } \\
\text { Hussain L et al (46) }\end{array}$ \\
\hline 20 & Trigonella foenum graecum (Linn.) & Methika & Anti-Inflammatory, Analgesic & Vyas $S$ et al (47) \\
\hline 21 & Vitex negundo (L.) & Nirgundi & Anti-Inflammatory, Analgesic & $\begin{array}{l}\text { Subramani J et al (48) } \\
\text { Telang RS et al (49) }\end{array}$ \\
\hline 22 & Cisus quandrangularis Wall. & Asthisamharaka & Anti-Inflammatory, Analgesic & Bhujade A et al (50) \\
\hline
\end{tabular}

Out of the 23 herbal drugs identified in the study area, various pre-clinical and clinical scientific studies carried out on 21 single herbal drugs revealed its anti-inflammatory, analgesic, Anti arthritic and antirheumatic activities and have shown remarkable effects in various concentrations.(Table 4). The antiinflammatory and analgesic activities may be due to the presence of flavonoids and other polyphenols, however further studies are required to understand molecular mechanisms of action against inflammation (51).

\section{Conclusion}

Present study concluded that the majority of the elderly tribal population of Karanja Ghadge block is suffering from Multiple joint pain, Low back pain, Rheumatoid arthritis, osteoarthritis etc. MSDs and dependent on traditional healers for their treatment. The changing life style, environmental circumstances and dietetic habits may be the chief contributing factors for the onset of the disease. Pharmacological properties and experimental studies conducted on plant species treating MSDs proved tribal peoples in depth knowledge of herbal drugs growing around them treating musculoskeletal diseases. Due to easy availability, simple method of preparation and administration, tribal people prefer herbal drugs for their treatment. If further such studies are to be designed for screening and isolating novel drugs with analgesic, anti inflammatory, anti arthritic potential from these identified plant drugs from the study area, it will be boon to MSD patients to reduce ache or inflammation with minimum or no side effects.

\section{References}

1. Cavero RY, Calvo MI. Medicinal plants used for musculoskeletal disorders in Navarra and their pharmacological validation, J. Ethnopharmacol, 2015; 168; 255-259.

2. Musculoskeletal conditions [Internet]. World Health Organization. World Health Organization; [cited 2019 Dec 1]. Available from: https:// www.who.int/ news-room/fact-sheets/detail// musculoskeletalconditions.

3. Marks D, Comans T, Bisset L, Scuffham PA. Substitution of doctors with physiotherapists in the management of common musculoskeletal disorders: a systematic review. Physiotherapy, 2017; 103 (4);341- 51

4. National Health porter, https://www.nhp.gov.in/ disease/musculo-skeletal-bone-joints-/osteoarthritis accesses on 2/12/2019 at 11 am

5. Gam AN, Johannsen F. Ultrasound therapy in musculoskeletal disorders: a meta analysis, Pain 1995; 63 (1); 85-91

6. Aletaha D, Kapral T, Smolen J. Toxicity profiles of traditional disease modifying antirheumatic drugs for rheumatoid arthritis, Ann. Rheum. Dis. 2003; 62 (5); 482-486.

7. Bodeker G, Kronenberg F, A public health agenda for complementary, alternative, and traditional medicine, Am. J. Public Health, 2002; 92 (10);1582-1591.

8. Rathi B, Rathi R. Ethno Medicinal documentation of plants used in the treatment of skin diseases by the tribal's of Karanja Ghadge Tahsil of Wardha District $\mathrm{Jr}$ of School of Adv studies, Jan -June2019;2(1);22-26

9. Gupta D, Mathur A, Patil GI, Tippanawar HK, Jain A, Jaggi N. et al. Prevalence of musculoskeletal disorder and alternative medicine therapies among dentists of North India: a descriptive study Pharmacogn Res,2015;4;350-354

10. Malik K, Ahmad M, Zhang G, Rashid N, Zafar M, Sultana S. et al Traditional plant based medicines used to treat musculoskeletal disorders in Northern Pakistan, European Journal of Integrative Medicine, 2018; 19; 17-64

11. Acharya Susruta, Susruta Samhita. Sharma AR (editor). Reprint Vol. II, Chikitsa Sthana, Svedavacharaniya Chikitsa Adhyaya, 32/3. Varanasi; Chaukhambha Sanskrit Samsthan; 2004, $416 p$

12. Acharya Susruta, Susruta Samhita. Sharma AR (editor). Reprint Vol. II, Chikitsa Sthana, Vatavyadhichikitsitam, 4/8. Varanasi; Chaukhambha Sanskrit Samsthan; 2004, 205p

13. Benson HA. Transdermal drug delivery: Penetration enhancement techniques. Curr Drug Deliv $2005 ; 2 ; 23-33$

14. Available from: htpp:// www.sbcollegeofpharmacy.com/research_pub5.htm [Last accessed on 15 March 2020]. 
15. Atchison JW, Herndon CM, Rusie E. NSAIDs for musculoskeletal pain management: current perspective and strategies to improve safety. J Manag Pharm Care, 2013; 19(9);1-19

16. Charaka Samhita of Agnivesh, Shashtri K (editor) Sutrasthana 28/27, Chaukhambha Sanskrit SansthanVaranasi, $4^{\text {th }}$ edition, $1996,432 p$

17. Shashtri K Charaka Samhita of Agnivesh Sutrasthana 26/5, Chaukhambha Sanskrit SansthanVaranasi, $4^{\text {th }}$ edition, $1996,348 \mathrm{p}$

18. Shashtri K Charaka Samhita of Agnivesh Sutrasthana 26/4, Chaukhambha Sanskrit SansthanVaranasi, $4^{\text {th }}$ edition, $1996,347 \mathrm{p}$

19. Jayanthi MK, Dhar M, Anti-inflammatory effects of Allium Sativum (Garlic)in experimental rats Biomedicine, 2011; 31(1); 84-89

20. Dange SV, Mathew J, Angana D, Tilak AV, Jadhav M. Evaluation of the analgesic efficacy of garlic shoots extract in experimental pain models in mice, International Journal of Basic and Clinical Pharmacology, 2016; Vol 5(6); 2393-2396

21. Bachhav RS, Gulecha VS, Upasani CD. Analgesic and anti-inflammatory activity of Argyreia speciosa root Indian J Pharmacol. 2009 ; 41(4); 158-161

22. Doss A, Anand SP. Preliminary Phytochemical Screening of Asteracantha longifolia and Pergularia daemia, World Applied Sciences Journal 2012; 18 (2); 233-235

23. Malairajan P, Geetha G, Narasimhan S, Jessi Kala Veni K. Analgesic activity of some Indian medicinal plants. Journal of Ethnopharmacology,2006; 19; 425-428.

24. Das S, Das S, Das MK, Basu SP, anti-inflammatory Evaluation of effect of Calotropis gigantea and Tridax procumbens on Wistar albino rats. J. Pharm. Sci. \& Res.2009; 1(4);123-126.

25. Kulkarni YA, Aggarwal S. Effect of Jyotishmati (Celastrus paniculatus) seeds in animal models of pain and inflammation. Journal of Ayurveda and Integrative medicine, 2015;6(2);82-88

26. Parimala1 S, Shashidhar Gh, Ch.Sridevi, Jyothi V, Suthakaran R. Anti- inflammatory activity of Celastrus paniculatus seeds. International Journal of PharmTech Research, 2009; 1(4);1326-1329

27. Sarvankumar G. Evaluation Of Analgesic and AntiInflammatory activity of methanolic extract of Cocculus hirsutus leaves Irjp 2011; 2 (12);230-234

28. Mujumdar AM. Anti-inflammatory activity of Curcuma amada Roxb. in Albino rats, Indian Journal of Pharmacology, 2000; 32;375-377

29. Rajurkar R, Jain R, Matake N, Aswar P, Khadbadi $\mathrm{S}$. Antiinflammatory action of Abutilon indicum L. sweet leaves by HRBC membrane stabilization, Research Journal of pharmacy and Technology, 2009; 2(2); 415-416.

30. Bhajipale NS. Evaluation of Anti-Arthritic Activity of Methanolic Extract of Abutilon indicum International Journal of Ayurvedic and Herbal Medicine, 2012; 2(3); 598- 603.

31. Pandey S, Chaudhary A. A review On Rasna Saptak Kwatha: An Ayurvedic polyherbal formulation for arthritis Int. J. Res. Ayurveda Pharm, 2017; 8 (Suppl 1); 4-11

32. Pandey PS, Trigunaya A. Anti-inflammatory and anti-arthritic activities of the mixture of flavonoids isolated from Pluchea lanceolata. Ijppr. Human, 2018;13 (4); 37-43

33. Raval ND, Ravishankar B., Analgesic effect of Lepidium sativum Linn. (Chandrashura) in experimental animals, AYU 2010 Jul-Sep; 31(3); 371-373

34. Raval ND, Ravishankar B Ashok B , Anti-inflammatory effect of Chandrashura (Lepidium sativum Linn.) an experimental study AYU Jul-Sep 2013; Vol 34(3); 302-304

35. Bhowmick R, Das A, Das B. In Vivo analgesic, Antipyretic, and Anti-inflammatory potential in swiss albino mice and in vitro thrombolytic activity of Hydroalcoholic extract From Litsea glutinosa leaves, Biological Research 2014; 47;56 doi:10.1186/0717-6287-47-56 http:// www.biolres.com/content/47/1/56

36. Bhattacharya A. Anti-pyretic, anti-inflammatory and analgesic effects of leaf extract of drumstick tree, Journal of Young Pharmacists 2014; 6(4); 20-24

37. Lalrinzuali K, Vabeiryureilai M, Jagetia G. Investigation of the Anti-inflammatory and Analgesic activities of ethanol extract of stem bark of Sonapatha (Oroxylum indicum) in vivo, International Journal of Inflammation Vol 2016, Article ID 8247014, 8 pages.

38. Fang S H, Rao YK, Tzeng YM. Anti-oxidant and inflammatory mediator's growth inhibitory effects of compounds isolated from Phyllanthus urinaria, Journal of Ethno-pharmacology, 2008; 116(2);333340

39. Ganesh M. Anti-inflammatory and analgesic effects of Pongamia glabra Leaf gall extract Pharmacology online $2008 ; 1 ; 497-512$

40. Gokani RH, Lahiri SK, Santani DD, Shah MB. Evaluation of anti-inflammatory and antioxidant activity of Premna integrifolia root. J Complement Integr Med. 2011; 8(1);1216-1222

41. Khatun H, Majumder R, Al Mamun, Alam k, Ibne Jami K, Alum B. Preliminary pharmacological activity of the methanolic extract of Premna integrifolia barks in rats Avicenna J Phytomed. 2014;4(3);215-24

42. Ilavarasan R. Anti-inflammatory and free radical scavenging activity of Ricinus communis root extract. Journal of Ethnopharmacology. $2006 ; 103 ; 478-480$

43. Sapan BJ, Seema GC. Comparative clinical study of Ricinus communis in the management of sandhigata vata (Osteoarthritis) World J Pharm Sci 2015; 4(6): 832-840

44. Gupta A. Evaluation of analgesic activity of Terminalia arjuna (Roxb.) W. \& A. Bark-A tribal claim, MD thesis, Departement of Dravyaguna, I.P.G.T. \& R.A, Jamnagar, 2012.

45. Sumanlata, Suman A, Sharma R, Khan A. Evaluation of anti inflammatory and antipyretic 
effect of aqueous extract of Tinospora cordifolia in rats, International Journal of Research \& Review, 2019;6(8);340-346

46. Hussain L, Muhammad S, H. Akash, Noor-Ul Ain, Rehman K, Ibrahim M, The Analgesic, antiinflammatory and anti-pyretic activities of Tinospora cordifolia, Adv Clin Exp Med, 2015; 24(6); 957-964

47. Vyas S, Agrawal R, Solanki P, Trivedi P. Analgesic and anti-inflammatory activities of Trigonella Foenum-Graecum(Seed) Extract Acta Poloniae Pharmaceutica ñ Drug Research, 2008; Vol. 65 (4); 473-476

48. Subramani J, Damodaran A, Kanniappan M, and Mathuram LN, Anti-inflammatory effect of petroleum ether extract of Vitex negundo leaves in rat models of acute and subacute inflammation. Pharmaceutical Biology 2009; 47(4); 335-339

49. Telang RS, Chatterjee S, Varshneya C. Studies on analgesic and anti-inflammatory activities of Vitex negundo Linn. Indian J Pharmacol 1999; 31;363-6.

50. Bhujade A, Suhas Talmale and Patil MB. In vivo Studies on antiarthritic activity of Cissus quadrangularis against adjuvant induced arthritis, $\mathrm{J}$ $\mathrm{C} 1 \mathrm{in} \mathrm{Cel1}$ I m munol $2015 ; 6 ; 327$ doi:10.4172/2155-9899.1000327

51. Manaheji H, Jafari S, Zaringhalam J, Rezazadeh S, Taghizadfarid R, Analgesic effects of methanolic extracts of the leaf or root of Moringa oleifera on complete Freund's adjuvant-induced arthritis in rats, Zhong Xi Yi Jie He Xue Bao , 2011; 9 (2); 216 222. 